УДК 159.944 .4

DOI https://doi.org/10.32838/2709-3093/2021.3/14

Поджіо T.Ю.

Національна академія державного управління при Президентові України

\title{
АНАЛІЗ ПСИХОДІАГНОСТИЧНОГО ІНСТРУМЕНТАРІЮ ДЛЯ ДОСЛІДЖЕННЯ ПРОФЕСІЙНОГО ВИГОРАННЯ НАУКОВО-ПЕДАГОГІЧНИХ ПРАЦІВНИКІВ ЗАКЛАДІВ ВИЩОї ОСВІТИ
}

У статті презентовано результати теоретичного аналізу можливостей застосування психодіагностичного інструментарію для вивчення синдрому професійного вигорання. Зазначено, що проблема професійного вигорання стає все більш актуальною на тлі подій, що були спричинені пандемією COVID-19: карантинні заходи, локдаун, швидкий перехід на дистанційне навчання, необхідність поєднувати професійну активність із домашніми справами («робота на дому»). Емоиійне виснаження, що супроводжує людей під час пандемії, часто детермінує розгортання професійного вигорання.

Теоретичний аналіз літератури засвідчив, щзо у психологічних дослідженнях західних країн зазвичай використовують такі два методичні підходи для вивчення того або іншого психологічного явища: методи непрямої взаємодї з досліджуваним (Unobtrusive Measures) i активні методи (Reactive Methods). Було визначено, що, незважсаючи на значну кількість теоретичних та практичних досліджень, термін «професійне вигорання» не належить до чітко визначених понять у системі психологічних знань. Автори наукових праць та досліджень використовують різні варіанти перекладу англійського терміна "bитпоит".

Класичні методики діагностики виникнення та розвитку професійного вигорання були розроблені Х. Маслач та В. Бойко. Кожна з методик спирається на теоретичну модель, яка містить базові конструкти професійного вигорання (емоційне виснаження, деперсоналізаиія, редукція особистих досягнень) та визначає фази вигорання, як-от: тривожна напруга, виснаження, резистенція.

Для діагностики перших симптомів синдрому емоційного вигорання науково-педагогічних прачівників закладів вищої освіти доцільно використовувати тест «Експрес-оиінка вигорання» (В. Каппоні, Т. Новак).

Визначено, що перспективою подальших досліджень є здійснення аналізу динаміки й особливостей розвитку синдрому професійного вигорання прачівників закладів освіти в умовах дистанційного та змішаного навчання.

Ключові слова: вигорання, професійне вигорання, психодіагностика, психодіагностичний інструментарій, професійне вигорання викладачів.

Постановка проблеми. У контексті світової економічної кризи, політичної нестабільності, стрімкого розвитку технологій та загострення соціальних проблем прискорюється темп життя, постійно підвищуються складність та інтенсивність професійних завдань, посилюється конкуренція на ринку праці, підвищується офіційний вік активної працездатності - усе це призводить до нової якості професійних стресових ситуацій, зростання їх кількості й інтенсивності. Як наслідок, емоційне перевантаження, стреси на роботі та, урешті-решт, професійне вигорання трапляються все частіше.

Особливо питання професійного вигорання загострилося на тлі пандемії, що була спричинена вірусом COVID-19. Вимушений різкий перехід на дистанційну форму навчання через запровадження локдауну спричинив значне психічне та фізичне навантаження на науково-педагогічних працівників закладів вищої освіти. Значна кількість викладачів були змушені опанувати новітні цифрові технології в дуже обмежений часовий термін.

Сучасні дослідження, що реалізуються на тлі кризи, спричиненої COVID-19, фіксують зростання емоційного вигорання, що, у свою чергу, позначається і на професійному вигоранні людини [1]. Також дослідження фіксують загострення синдрому професійного вигорання у викладачів вищих навчальних закладів України, що 
розгортається під впливом карантинних обмежень [10].

Отже, бачимо, що профілактика та подолання синдрому професійного вигорання залишається однією з актуальних проблем, пов'язаних із забезпеченням ефективності професійної діяльності, підтримкою високого рівня функціональності, а також охороною здоров'я співробітників у будь-якій організації чи установі.

Актуальність дослідження синдрому професійного вигорання в науково-педагогічних працівників закладів вищої освіти пов' язана ще й 3 тим, що психоемоційний стан науково-педагогічного працівника відображається на навчально-виховному процесі та якості підготовки майбутніх фахівців.

Аналіз останніх досліджень і публікацій. Загальнометодологічний підхід до проблеми «вигорання» реалізовано в роботах Б. Ананьєва, В. Бойко, Л. Виготського, С. Джексон, К. Леонгарда Х. Маслач, Г. Френдерберга; наукові уявлення про синдром «емоційного вигорання» обгрунтовували такі вчені, як: В. Зігерт, М. Лейтер, Г. Робертс, Є. Семенова; теоретико-методологічні положення про вплив синдрому «емоційного вигоряння» на психологічний стан людини викладені в роботах К. Роджерс, С. Грімейл, А. Адлер.

Зміст i структуру професійного вигорання розглядають у своїх працях Х. Алієв, М. Буриш, С. Гремлінг, Дж. Грінберг, Л. Карамушка, Л. КитаєвСмик, Н. Левицька, Х. Маслач, Е. Махер, В. Орел, Т. Форманюк, Г. Фрейденбергер, У. Шауфелі й інші вітчизняні та зарубіжні вчені. Дослідженню особливостей перебігу професійного стресу та його проявів у працівників закладів освіти присвячені праці О. Баранова, Т. Зайчикова, В. Зеньковського, Л. Колеснікової, А. Шафранової.

Проблема діагностики синдрому професійного вигорання висвітлена в роботах закордонних і вітчизняних учених, серед яких В. Бойко, Н. Водоп'янова, Х. Маслач та інші. Над пошуком засобів профілактики та корекції зазначеного синдрому працювали Х. Фрейденбергер, О. Козлова, К. Кондо, Д. Трунов та інші науковці.

Постановка завдання. Метою статті $є$ здійснення аналізу наявного психодіагностичного інструментарію, який може бути використаний для вивчення проявів професійного вигорання науково-педагогічних працівників 3ВО. Для досягнення поставленої мети застосовувалися такі методи дослідження: системно-структурний аналіз, узагальнення даних наукової літератури щодо методичних засад реалізації досліджень у сфері проблематики професійного вигорання.
Виклад основного матеріалу дослідження. Питання розроблення адекватного психологічного інструментарію для дослідження психічних особливостей людини посідають важливе місце в науковій психології. Варто зауважити, що застосування опитувальників, тестів, анкет тощо дозволяє отримати інформацію, яка є важливою для запобігання професійному вигоранню, його профілактики. Теоретичний аналіз літератури засвідчив, що у психологічних дослідженнях зазвичай використовують такі методичні підходи для вивчення того або іншого психологічного явища. Зокрема, у психологічній науці західних країн методи дослідження розділяються на такі дві групи: методи непрямої взаємодії з досліджуваним (Unobtrusive Measures) i активні методи (Reactive Methods) [5].

Основним правилом для методів непрямої взаємодії є те, що досліджуваний не знає про те, що є учасником дослідження. Необхідно зазначити, що методи непрямої взаємодії розподілені на приховані й опосередковані. До прихованих відносять структуроване спостереження, коли досліджуваний не знає, що за ним ведеться спостереження. Опосередковані включають у себе аналіз даних, які дослідник може здобути без взаємодії з учасником дослідження (аналіз фото, документів, архівних даних (контент-аналіз також) тощо).

Пряма взаємодія включає використання опитувальників, тестів, інтерв'ю, бесіди. Як бачимо, це означає пряме контактування з учасниками дослідження / респондентами [4].

Отже, можемо констатувати, що збір даних може реалізовуватись 3 опорою на різні стратегіï, які обираються відповідно до цілей та мети дослідження. Зауважимо, що процедура та перебіг дослідження мають бути логічно продуманим та структурованим - це сприятиме збору достовірних даних.

Незважаючи на значну кількість теоретичних та практичних досліджень, термін «професійне вигорання» не належить до чітко визначених понять у системі психологічних знань. Автори наукових праць та досліджень використовують різні варіанти перекладу англійського терміна “burnout”, а саме: «професійне вигорання» (Т. Ронгінська, Л. Карамушка, Л. Юр’єва), «емоційне вигорання» (В. Бойко, В. Дудяк), «емоційне згорання» (Т. Яценко, Т. Форманюк), «емоційне перегорання» (В. Від), «емоційне вигоряння» (Н. Самикіна, О. Коноплицька, Т. Вашека, Н. Янушева), «психічне вигорання» (О. Рукавішніков, Н. Водоп’янова). 
Метою нашого наукового пошуку було визначення методичного інструментарію, який доцільно використовувати в дослідженні професійного вигорання в науково-педагогічних працівників ЗВО. Теоретичний аналіз засвідчив, що вивчення соціально-психологічних аспектів формування та проявів синдрому професійного вигорання в науково-педагогічних працівників може бути реалізовано із застосуванням таких психодіагностичних методик: тест-опитувальник «Професійне вигорання» (МВI, Х. Маслач); тест «Експресс-оцінка вигорання» (В. Каппоні, Т. Новак); опитувальник «Емоційне вигорання» (В. Бойко). Охарактеризуємо зазначені методики, обгрунтуємо їх вибір.

Однією з найперших методик, що була спрямована на вивчення професійного вигорання людини, була методика MBI (Maslach Burnout Inventory), яку в 1982 р. опублікувала американська дослідниця X. Маслач [2]. Зауважимо, що шкала вимірів даної тестової методики і нині широко використовується в емпіричних дослідженнях як найпопулярніший інструмент вимірювання ступеня професійного вигорання, зазвичай є основою для розроблення інших тестових методик.

Тест-опитувальник «Професійне вигорання» (MBI) базується на теорії синдрому вигорання, розробленій К. Маслач і С. Джексон [3], дає можливість визначити такі основні складові частини синдрому професійного вигорання:

- емоційне виснаження;

- деперсоналізація;

- редукція особистих досягнень.

Варто зазначити, що методика має варіанти опитувальників, які можуть бути використані в дослідженні різних професій типу «людина людина». Методика дослідження є досить компактною у використанні та включає в себе 22 питання, тому іiї доцільно застосовувати в ситуації, коли потрібно швидко провести опитування. Варто зауважити, що на основі результатів, отриманих за допомогою опитувальника, може бути розроблена індивідуальна програма подолання синдрому професійного вигорання як для окремої особистості, так і для групи людей, які працюють у тій самій організації, наприклад у закладі вищої освіти [7]. Також ця методика може бути успішно використана під час проведення консультацій та тренінгів для діагностики або самодіагностики; може бути використана у проведенні емпіричних досліджень.

Тест «Експрес-оцінка вигорання» (В. Каппоні, T. Новак) призначений для діагностики перших симптомів синдрому емоційного вигорання, для його розпізнавання [8]. Дана експрес-оцінка вигорання містить 10 питань. Залежно від кількості набраних балів, за результатами відповідей респондента, професійне вигорання людини може бути віднесено до низького, середнього, високого або дуже високого рівня. Отже, дану методику доцільно використовувати як перший етап під час виявлення перших ознак професійного вигорання науково-педагогічних працівників ЗВО. Зауважимо, що дана методика може бути використана також із метою самодіагностики.

Опитувальник «Емоційне вигорання» базується на моделі емоційного вигорання, що розроблена В. Бойко, який визначає емоційне вигорання як «придбаний стереотип емоційної, частіше професійної, поведінки» [6]. Рівень емоційного вигорання оцінюється за 12 шкалами, які групуються відповідно до таких фаз:

- фаза «Тривожна напруга»: провісник і «механізм, що запускає», формування емоційного вигоряння. Напруга має динамічний характер, що зумовлюється сталістю, що вимотує, або посиленням психотравмувальних чинників;

- фаза «Виснаження»: характеризується більшменш вираженим падінням загального енергетичного тонусу й ослабленням нервової системи;

- фаза «Резистенція»: опір стресу, що наростая.

Надамо характеристику означеним фазам, які унаочнюють процес розгортання емоційного вигорання.

Фаза «Тривожна напруга», або нервова напруга - це механізм, що запускає професійне вигорання та проявляється в чотирьох симптомах:

1. Переживання психотравмувальних обставин: проявляється усвідомленням, що підсилюється психотравмувальними чинниками професійної діяльності.

2. Незадоволеність собою: проявляється в почутті такого, що зростає, інколи постійного незадоволення собою, вибраною професією, своєю посадою; посилюється в разі неможливості конструктивно вирішити питання.

3. Загнаність у клітку: проявляється в почутті безвиході, гостро переживається, коли психотравмувальні обставини дуже давлять, усунути їх неможливо. Це стан інтелектуально-емоційного затору, тупика.

4. Тривога й депресія: виявляється у тривожно-депресивній симптоматиці, що стосується професійної діяльності в особливо складних обставинах. Почуття незадоволеності діяльністю й собою породжує потужні енергетичні напруги у 
формі переживання ситуативної або особистісної тривоги.

Фаза «Резистениія» - це формування захисту, яке проявляється в таких симптомах вигорання:

1. Неадекватне виборче емоційне реагування: спостерігається тоді, коли професіонал перестає відчувати різницю між двома явищами, що принципово відрізняються: економічним проявом емоцій і неадекватним виборчим емоційним реагуванням. Тобто професіонал неадекватно «заощаджує» на емоціях, обмежує емоційну віддачу через вибіркове реагування на ситуації об'єктів діяльності; емоційний контакт встановлюється не з усіма суб'єктами професійної діяльності, а за принципом «хочу- не хочу» - неадекватним або виборчим образом.

2. Емоційно-моральна дезорієнтація: проявляється в тому, що у працівника емоції не пробуджуються або не досить стимулюють моральні почуття. Він не проявляє адекватного емоційного ставлення, захищає свою стратегію: виправдовується перед собою за допущену брутальність або відсутність уваги до об’єкта професійної діяльності, раціоналізує свої вчинки або проєктує провину на суб'єкта, замість того щоб адекватно визнати свою провину.

3. Розширення сфери економії емоцій: проявляється поза професійною діяльністю - у спілкуванні із приятелями та знайомими. На роботі фахівець так утомлюється від контактів, розмов, відповідей на питання, що йому не хочеться спілкуватися навіть із близькими.

4. Редукція професійних обов'язків - виявляється у спробах полегшити або скоротити обов'язки, які вимагають емоційних витрат. Час формування даної стадії, у середньому, від 5 до 15 років.

Фаза «Виснаження» характеризується більшменш вираженим падінням загального тонусу й ослабленням нервової системи. Емоційний захист стає невід'ємним атрибутом особистості. Дана фаза також проявляється в низці симптомів:

1. Емоційний дефіцит: проявляє себе у відчутті, що емоційно професіонал не може ефективно вступати в суб'єкт-об'єктні стосунки у професійній діяльності.

2. Емоційна віддаленість: працівник майже цілком виключає емоції зі сфери своєї професійної діяльності. Його майже ніщо не хвилює, не викликає емоційного відгуку: ні позитивні, ні негативні обставини.

3. Особистісна віддаленість, або деперсоналізація: проявляється в широкому діапазоні умонастроїв і вчинків професіонала у сфері спілкування. Насамперед відзначається цілковита або часткова втрата інтересу до людини - об'єкта професійної діяльності.

4. Психосоматичні та психовегетативні порушення: виявляються на рівні психічного й фізичного самопочуття. Даний симптом зазвичай утворюється за умовно рефлекторним зв'язком негативної властивості: багато чого з того, що стосується суб'єктів професійної діяльності, провокує відхилення в соматичних і психічних станах. Стадія може формуватися від 10 до 20 років [9].

Необхідно зазначити, що модель В. Бойко описує фази професійного вигорання з характерними для них симптомами. Емоційне вигорання розглядається як професійна деформація особистості, що виникає під впливом низки чинників: зовнішніх (хронічно напружена психоемоційна діяльність, дестабілізуюча організація діяльності, підвищена відповідальність за професійні функції й операції, що виконуються, неблагополучна психологічна атмосфера професійної діяльності) та внутрішніх (схильність до емоційної ригідності, інтенсивна інтеріоризація, слабка мотивація емоційної віддачі у професійній діяльності, морально-етичні дефекти та дезорієнтація особистості).

Методика діагностики рівня емоційного вигорання В. Бойко є найбільш комплексною і дає можливість системно і детально проаналізувати міру вираженості дванадцяти симптомів синдрому професійного вигорання.

Перевагою цієї методики є можливість отримання окремих даних за кожним із симптомів та детальної інформації про сформованість кожної 3 фаз професійного вигорання. До недоліків методики дослідження «Емоційне вигорання» можна віднести великий обсяг стимульного матеріалу, складність обробки даних, що робить цю методику дослідження досить часозатратною як для респондентів, так і для дослідників.

Зауважимо, що надійність та вірогідність результатів дослідження має забезпечуватися не лише адекватним підбором психодіагностичного інструментарію, а й репрезентативністю вибіркової сукупності та загальною процедурою дослідження, що мають відповідати меті та поставленим завданням.

Висновки. Професійне вигорання в сучасній психології визначається як синдром, що характеризується групою вищевказаних симптомів. Класичні методики діагностики виникнення та розвитку професійного вигорання були розроблені Х. Маслач і В. Бойко. Кожна 3 методик 
спирається на теоретичну модель, яка містить базові конструкти професійного вигорання (емоційне виснаження, деперсоналізація, редукція особистих досягнень) та визначає фази вигорання, як-от: тривожна напруга, виснаження, резистенція. Для діагностики перших симптомів синдрому емоційного вигорання науково-педагогічних працівників 3ВО доцільно використовувати тест «Експрес-оцінка вигорання» (В. Каппоні, Т. Новак).
Цінність кожної з вищезгаданих методик полягає в можливості виявити наявність, оцінити рівень розвитку синдрому професійного вигорання; визначити сформованість його окремих складових частин за допомогою різних критеріїв.

Перспективу подальших досліджень убачаємо у здійсненні порівняльного аналізу динаміки й особливостей розвитку синдрому професійного вигорання працівників закладів освіти різних ланок в умовах дистанційного та змішаного навчання.

\section{Список літератури:}

1. Lufkin B. How to avoid burnout amid a pandemic? URL: https://www.bbc.com/worklife/article/20200330covid-19-how-to-learn-a-new-skill-in-coronavirus-quarantine.

2. Maslach C. Job burnout: new directions in research and intervention. Current Directions in Psychological Science. 2003. Vol. 12. P. 189-192.

3. Maslach C., Schaufeli W. History and conceptual specificity of burnout. Recent development in theory and research. New York : Hemisphere Publ. Corp. 1993. 297 p.

4. Taylor J., Bogdan R., DeVault L. Introduction to Qualitative Research Methods. A Guidebook and Resource. New Jersey : John Wiley \& Sons, 2015.

5. Webb E. Unobtrusive Measures : Nonreactive research in the social sciences. Chicago : McNally, 1973.

6. Бойко В. Синдром «эмоционально выгорания» в профессиональном общении. Санкт-Петербург, 1999. 203 c.

7. Зайчикова Т. Діагностика та профілактика синдрому професійного вигорання у вчителів : методичні рекомендації. Київ ; Рівне, 2003. 24 с.

8. Каппони В., Новак Т. Сам себе авторитет. Санкт-Петербург : Питер, 1995. 158 с.

9. Современные проблемы исследования синдрома выгорания у специалистов коммуникативных профессий : коллективная монография / под ред. В. Лукьянова и др. Курск, 2008. 336 с.

10. Стефанчук А. Вплив карантинних обмежень на розвиток професійного вигорання викладачів вищих навчальних закладів України. Актуальні проблеми сучасної медичини : Вісник Української медичної стоматологічної академії. 2021. № 21 (1). C. 141-145. DOI: 10.31718/2077-1096.21.1.141.

\section{Podzhio T.Yu. PSYCHODIAGNOSTIC TOOLS ANALYSIS FOR HIGHER EDUCATION INSTITUTIONS SCIENTIFIC AND PEDAGOGICAL STAFF BURNOUT INVESTIGATION}

The article presents the results of a theoretical analysis of the possibilities to use psychodiagnostic tools to study the burnout syndrome. It is noted that the problem of burnout is becoming increasingly relevant against the background of the events caused by the COVID-19 pandemic: quarantine measures, lockdown, rapid transition to distance learning, the need to combine professional activity with household chores ("work at home"). The emotional exhaustion that accompanies people during a pandemic often determines the development of burnout.

Theoretical analysis of the literature showed that the following two methodological approaches to study a psychological phenomenon are usually used in psychological research in Western countries: methods of indirect interaction with the subject (Unobtrusive Measures) and active methods (Reactive Methods).

It was determined that despite a significant amount of theoretical and practical research, the term "professional burnout" does not refer to clearly defined concepts in the system of psychological knowledge. Authors of scientific papers and research use different versions of translation of the English term "burnout".

Classical methods for diagnosing the occurrence and development of staff burnout were developed by X. Maslach and V. Boyko. Each of the methods is based on a theoretical model that contains the basic constructs of burnout (emotional exhaustion, depersonalization, reduction of personal achievements) and determines the phases of burnout: anxiety, exhaustion, resistance.

To diagnose the first symptoms of the syndrome of emotional burnout of scientific and pedagogical workers of the Free Economic Zone, it is advisable to use the test "Express burnout assessment" (V. Kapponi, T. Novak).

It is determined that the prospect of further research is to analyze the dynamics and features of educational institutions staff burnout syndrome development in terms of distance and blended learning.

Key words: burnout, staff burnout, psychodiagnostics, psychodiagnostic tools, scientific and pedagogical staff burnout. 